\title{
Novel PRRT2 mutation in an African-American family with paroxysmal kinesigenic dyskinesia
}

\author{
Peter Hedera ${ }^{1 \dagger}$, Jianfeng Xiao ${ }^{2 \dagger}$, Andreas Puschmann ${ }^{3}$, Dragana Momčilović ${ }^{4}$, Steve W Wu ${ }^{5}$ and Mark S LeDoux ${ }^{2^{*}}$
}

\begin{abstract}
Background: Recently, heterozygous mutations in PRRT2 (Chr 16p11.2) have been identified in Han Chinese, Japanese and Caucasians with paroxysmal kinesigenic dyskinesia. In previous work, a paroxysmal kinesigenic dyskinesia locus was mapped to Chr 16p11.2 - q11.2 in a multiplex African-American family.

Methods: Sanger sequencing was used to analyze all four PRRT2 exons for sequence variants in 13 probands (9 Caucasian, 1 Caucasian-Thai, 1 Vietnamese and 2 African-American) with some form of paroxysmal dyskinesia.

Results: One patient of mixed Caucasian-Thai background and one African-American family harbored the previously described hotspot mutation in PRRT2 (c.649dupC, p.R217Pfs*8). Another African-American family was found to have a novel mutation (c.776dupG, p.E260*). Both of these variants are likely to cause loss-of-function via nonsense-mediated decay of mutant PRRT2 transcripts. All affected individuals had classic paroxysmal kinesigenic dyskinesia phenotypes.
\end{abstract}

Conclusions: Heterozygous PRRT2 gene mutations also cause paroxysmal kinesigenic dyskinesia in African-Americans. The c.649dupC hotspot mutation in PRRT2 is common across racial groups.

Keywords: PKD, PRRT2, African-American, ICCA, Hotspot mutation

\section{Background}

Paroxysmal kinesigenic dyskinesia (PKD, OMIM 128000), also known as episodic kinesigenic dyskinesia (EKD1) and paroxysmal kinesigenic choreoathetosis (PKC), is a rare autosomal dominant neurological disorder characterized by recurrent, brief attacks of involuntary movement usually triggered by sudden voluntary movement $[1,2]$. These attacks usually begin in childhood or early adulthood and may include various combinations of dystonia, chorea, and athetosis affecting the face, trunk, arms and legs. Oftentimes, PKD improves with age and most patients show a favorable response to anticonvulsant medications, particularly carbamazepine or phenytoin [1,2]. Recently, mutations in PRRT2 (Chr 16p11.2) have been causally associated with both familial and sporadic cases of PKD, infantile convulsions and choreoathetosis

\footnotetext{
*Correspondence: mledoux@uthsc.edu

${ }^{\dagger}$ Equal contributors

${ }^{2}$ Departments of Neurology, and Anatomy and Neurobiology, University of Tennessee Health Science Center, 855 Monroe Avenue, Suite 415 Link Building, Memphis, TN 38163, USA

Full list of author information is available at the end of the article
}

exercise-induced dyskinesia (PED), and paroxysmal nonkinesigenic dyskinesia-like (PNKD-like) syndromes in Han Chinese, Japanese and Caucasians [3-11].

PKD is clinically and genetically heterogeneous, and, in at least one British pedigree, does not map to Chr 16 [12]. Work to date suggests that fewer than $50 \%$ of patients with primary PKD harbor mutations in PRRT2 [6,8]. To expand the genotypic spectrum of PRRT2 mutations and examine the role of PRRT2 in other racial groups, we report the clinical and genetic data for 13 probands with paroxysmal dyskinesias including 1 Vietnamese, 1 mixed Caucasian-Thai and 2 African-Americans.

\section{Methods}

All human studies were performed in accordance with institutional review board guidelines at each participating institution, the Helsinki Declaration, and written informed consent for genetic studies and publication of clinical data was obtained from all subjects or, where participants were children, their parents. All genetic and phenotypic analyses and publication of the results were approved by the University of Tennessee Health Science 
Center Institutional Review Board (\#01-07346-XP). Subjects were acquired from outpatient clinics at participating institutions. Clinical diagnoses were made by means of history and examination by one or more boardcertified neurologists at each institution. Clinical and genetic details for 13 probands are presented Table 1 .

DNA was extracted from peripheral blood leucocytes using Roche's DNA Isolation Kit for Mammalian Blood (Indianapolis, IN, USA). DNA quantity and quality were analyzed with a NanoDrop ND-1000 spectrophotometer (Wilmington, DE, USA) and agarose gel electrophoresis. With Primer3 (frodo.wi.mit.edu), four pairs of PCR primers were designed to encompass the four PRRT2 exons and flanking intronic regions (Additional file 1 Table S1). For Sanger sequencing, PCR was performed using 50 ng of template DNA, 1X PCR buffer, $2.5 \mathrm{mM} \mathrm{MgCl}_{2}$ and $200 \mathrm{nM}$ of each primer in a $20-\mu \mathrm{l}$ reaction volume. The following cycling conditions were employed: $95^{\circ} \mathrm{C}$ for $15 \mathrm{~min} ; 35$ cycles at $95^{\circ} \mathrm{C}$ for $15 \mathrm{~s}, 60^{\circ} \mathrm{C}$ for $15 \mathrm{~s}$, and $72^{\circ} \mathrm{C}$ for $45 \mathrm{~s}$; and $72^{\circ} \mathrm{C}$ for $10 \mathrm{~min}$. After agarose gel confirmation, $5 \mu \mathrm{l}$ of the PCR products were cleaned using ExoSAP-IT ${ }^{\circledR}$ (United States Biochemical, Cleveland, $\mathrm{OH}, \mathrm{USA}$ ). Then, 1-2 $\mu \mathrm{l}$ of the purified PCR products were sequenced in the forward and reverse directions on the Applied Biosystems 3130XL Genetic Analyzer (Carlsbad, CA, USA). Control DNA samples (100 African-American and 100 Caucasian) were sequenced for detection of newly-identified PRRT2 mutations.

\section{Results}

Among 13 index cases with paroxysmal dyskinesias, two different mutations in three families were identified. A novel mutation was found in African-American Family A (Figure 1, c.776dupG, p.E260*). This mutation was not found in 100 African-American or 100 Caucasian normal controls. The proband was a 22-year-old female (Figure 1, III-3), who noticed the first attack of choreiform and dystonic movements in her hands and arms at age 12. Subsequent episodes also included dystonia in her legs and face. Her father and all three sisters have similar clinical features during attacks with dystonia in the face, arms and legs, along with chorea in the hands. Although DNA specimens were not available from her father and two older sisters, the c.776dupG mutation was confirmed in her youngest sister (III-4). All affected family members responded to either carbamazepine or phenytoin. Two of the three family members currently taking phenytoin did not tolerate carbamazepine due to sedative effects.

The previously reported hotspot mutation (c.649dupC, p.R217Pfs*8) was found in African-American Family B (Figure 1) and an individual of mixed Caucasian-Thai background. The c.649dupC variant was not found in
100 African-American or 100 Caucasian normal controls. Case 7 had late-onset ( $>20$ y) but otherwise classic carbamazepine-responsive PKD. Prior to initiation of therapy with carbamazepine, sudden movements were more likely to precipitate dystonic posturing when the patient was under psychological stress. Attacks often consisted of dystonic posturing of the left arm in abduction along with cervical dystonia. Occasionally, similar attacks affected the right side of the body. Although his Thai mother had no history of PKD, ICCA or BFIE and was found to be neurologically normal, Sanger sequencing revealed that she was a carrier, and several of her family members reportedly had infantile seizures.

No sequence variants were identified in the remaining 10 probands (9 Caucasian, 1 Vietnamese) with PED, ICCA, PKD or PNKD, 3 of whom had a positive family history. All but two of these individuals had early-onset $(<20$ y) paroxysmal dyskinesias. Age of onset, attack frequency and attack duration were much more variable among the mutation-negative cases in comparison to the patients with PRRT2 mutations.

\section{Discussion}

Candidate regions for PKD and ICCA were mapped to Chr 16 over a decade ago. PKD was linked to a $15.8 \mathrm{cM}$ region flanked by markers D16S685 and D16S503 on Chr 16q13-q22.1 with a maximum LOD score of 3.66 at D16S419 in a large Indian family [13]. This candidate region was telomeric to a locus identified in Japanese families with PKD [14], but showed overlap with a region identified in an African-American family with PKD [15]. A candidate region for ICCA had also been mapped to the pericentromeric region of Chr 16 in French [16] and Chinese [17] families.

Just recently, several distinct loss-of-function frameshift mutations leading to protein truncation or nonsensemediated decay in proline-rich transmembrane protein 2 (PRRT2) have been associated with PKD in numerous Han Chinese families [3-6]. A much smaller percentage of cases were associated with missense mutations (e.g., c.796C > T, p.R266W; c.913 G>A, p.G305R) [4,6]. In addition to classic carbamazepine-responsive PKD, the phenotypic spectrum of PRRT2 mutations includes cases of ICCA, BFIE, some "PNKD-like" syndromes, and PED [6-11]. PRRT2 is located on Chr 16p11.2, within the ICCA, Japanese PKD, and African-American candidate regions but outside the Indian PKD candidate region. The association of PRRT2 genotypes with specific neurological phenotypes may become apparent with the publication of additional well-characterized cases.

PRRT2 is a cell surface protein containing two predicted transmembrane domains and highly expressed in the developing nervous system, particularly the cerebellum [3]. Our study has shown that novel and hotspot 
Table 1 Clinical details and genetic results for subjects with paroxysmal dyskinesias

\begin{tabular}{|c|c|c|c|c|c|c|c|c|c|c|c|}
\hline Subject (Diagnosis) & $\begin{array}{l}\text { PRRT2 } \\
\text { Mutation }\end{array}$ & Age/Gender & Race & $\begin{array}{l}\text { Age at } \\
\text { onset(y) }\end{array}$ & $\begin{array}{l}\text { Family } \\
\text { history }\end{array}$ & $\begin{array}{l}\text { Attack } \\
\text { frequency }\end{array}$ & $\begin{array}{l}\text { Attack } \\
\text { duration }\end{array}$ & Triggers & $\begin{array}{l}\text { Involuntary } \\
\text { movements }\end{array}$ & $\begin{array}{l}\text { Anatomical } \\
\text { distribution }\end{array}$ & $\begin{array}{l}\text { Response to } \\
\text { anticonvulsants }\end{array}$ \\
\hline Family A, II-1 (PKD) & NA & NA/M & African-American & $10 y$ & Yes & $<100 /$ day & $10-20 \mathrm{sec}$ & SM & $\mathrm{D}, \mathrm{C}$ & $A, L$ & $\begin{array}{l}\text { carbamazepine }(+), \\
\text { phenytoin }(+)\end{array}$ \\
\hline Family A, III-1 (PKD) & NA & $28 y / F$ & African-American & $12 y$ & Yes & 20-30/day & $10-40 \mathrm{sec}$ & SM & $D, C$ & $F, A, L$ & phenytoin (+) \\
\hline Family A, III-2 (PKD) & NA & $25 \mathrm{y} / \mathrm{F}$ & African-American & $10 y$ & Yes & 50-75/day & $10-15 \mathrm{sec}$ & SM & $D, C$ & $A, L$ & carbamazepine $(+)$ \\
\hline Family A, III-3 (PKD) & c.776dupG & $22 y / F$ & African-American & $10 y$ & Yes & 30-40/day & $10-15 \mathrm{sec}$ & SM & $D, C$ & $F, A, L$ & $\begin{array}{l}\text { carbamazepine(+), } \\
\text { phenytoin }(+)\end{array}$ \\
\hline Family A, III-4 (PKD) & c.776dupG & $18 y / F$ & African-American & $13 y$ & Yes & 20-30/day & $10-60 \mathrm{sec}$ & SM & $D, C$ & $F, A, L$ & carbamazepine(+) \\
\hline Family B (PKD) & c.649dupC & $30 y / M$ & African-American & $12 y$ & Yes & 50/day & $10-60 \mathrm{sec}$ & SM & $D, C$ & $F, A$ & phenytoin (+) \\
\hline Case 7 (PKD) & c.649dupc & $27 y / M$ & Caucasian-Thai & $21 y$ & *Yes & 3-6/day & $<10 \mathrm{sec}$ & $S M, S$ & $\mathrm{D}$ & $F, A, L$ & carbamazepine $(+)$ \\
\hline Case 8 (PED) & None & $29 y / F$ & Caucasian & $<28 y$ & No & $<1 /$ day & $2-4 \mathrm{hrs}$ & Intense exercise & $\mathrm{D}$ & $F, A, L$ & clonazepam ( \pm ) \\
\hline Case 9 (PKD) & None & $18 y / M$ & Caucasian & $14 y$ & No & 5-8/day & $<15 \mathrm{sec}$ & SM & $\mathrm{D}$ & $F, A, L$ & carbamazepine $(+)$ \\
\hline Case 10 (ICCA) & None & $19 \mathrm{mo} / \mathrm{M}$ & Caucasian & $7 \mathrm{~m}$ & No & $>100 /$ day & $40-50 \mathrm{sec}$ & SM & $D, C, A$ & $F, A, L$ & carbamazepine $(+)$ \\
\hline Case 11 (PKD) & None & $41 \mathrm{y} / \mathrm{F}$ & Caucasian & $<33 y$ & Yes & $20-25 / \mathrm{mo}$ & 2-30 min & $S M, S$ & $\mathrm{D}$ & $F, A, L$ & $\begin{array}{l}\text { piracetam }( \pm) \\
\text { clonazepam }( \pm)\end{array}$ \\
\hline Case 12 (PKD) & None & $20 y / M$ & Caucasian & $3 y$ & No & 6-7/day & $5-60 \mathrm{sec}$ & $S M, S$ & $D, C, A$ & $F, A, L$ & carbamazepine $(+)$ \\
\hline Case 13 (PKD) & None & $18 \mathrm{y} / \mathrm{M}$ & Caucasian & $15 y$ & Yes & 2-5/day & $5-6 \mathrm{sec}$ & SM & $D$ & $F, A, L$ & carbamazepine $(+)$ \\
\hline Case 14 (PKD) & None & $18 y / F$ & Caucasian & $15 y$ & No & 3-4/day & $<10 \mathrm{sec}$ & SM, S & $D, C, A$ & $F, A, L$ & carbamazepine $(+)$ \\
\hline Case 15 (PKD) & None & $14 \mathrm{y} / \mathrm{M}$ & Vietnamese & $12 y$ & No & 10/day & $15-60 \mathrm{sec}$ & S & D & $A, L$ & acetazolamide (+) \\
\hline Case 16 (PKD) & None & $26 y / F$ & Caucasian & $16 y$ & No & 30/day & $20-30 \mathrm{sec}$ & SM & $D$ & $A$ & phenytoin (+) \\
\hline Case 17 (PNKD) & None & $6 y / F$ & Caucasian & $6 \mathrm{~m}$ & Yes & $2-10 / \mathrm{mo}$ & $3-60 \mathrm{~min}$ & $\begin{array}{l}\text { Fatigue, } \\
\text { sleep deprivation }\end{array}$ & $\mathrm{D}$ & $A, L$ & NA \\
\hline
\end{tabular}

Involuntary movements: D-dystonia, C-chorea, and A-athetosis. Anatomical distribution: F-face, A-arm, and L-leg.

Triggers: SM-sudden movement and S-stress. NA, DNA or clinical detail not available. Response to anticonvulsants:
+ , good to excellent response and \pm , partial response, ${ }^{*}$, early childhood seizures on maternal (Thai) side of the family. 


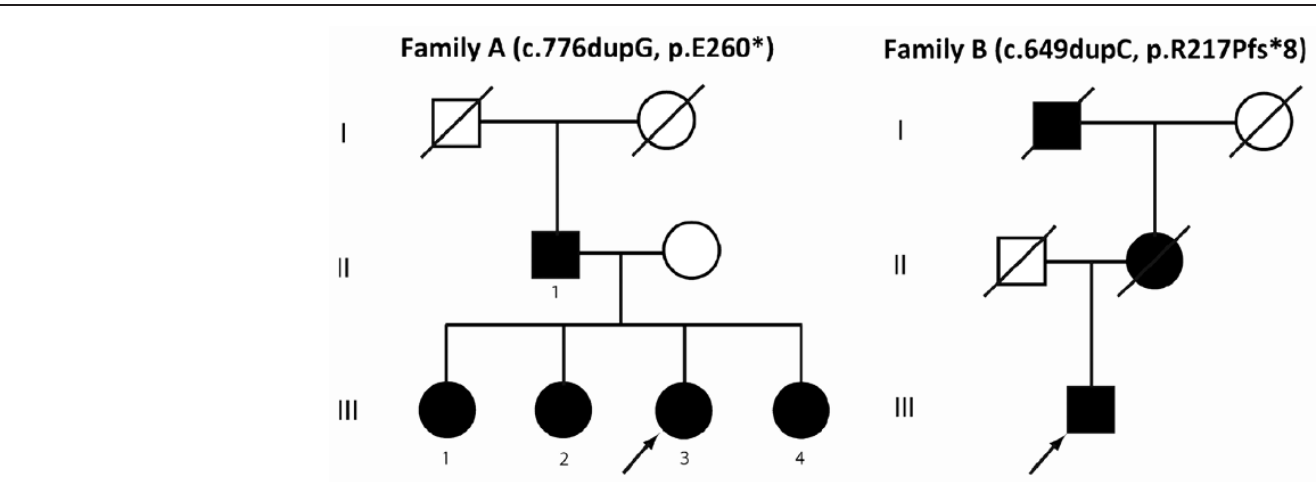

Figure 1 African-American PKD pedigrees. Males are represented by squares, females by circles. Affected individuals are represented by filled/ black symbols and asymptomatic family members by empty/white symbols. Symbols of deceased individuals are slashed. Probands are denoted with arrows.

mutations in PRRT2 are associated with classic PKD in African-Americans. The c.776dupG and c.649dupC mutations are heterozygous SNindels (single nucleotide insertions or deletions) predicted to cause nonsensemediated decay of mutant transcripts rather than expression of a truncated protein [18,19]. SNindels occur at an estimated frequency of 0.887 per $10 \mathrm{~kb}$ of genomic DNA with more than half occurring in regions with mononucleotide repeats [19]. The novel c.776dupG mutation is located within a 6 nucleotide (nt) poly-G tract and the c.649dupC hot spot mutation is in a $9 \mathrm{nt}$ poly- $\mathrm{C}$ tract. SNindels within regions of mononucleotide repeats may arise from replication slippage [19].

\section{Conclusions}

The novel c.776dupG mutation and c.649dupC hot spot mutation identified in our African-American families with classic PKD expands the molecular and racial spectrums of PRRT2 mutations. As evidenced from our patient of mixed Caucasian-Thai descent, the penetrance of PRRT2 mutations may depend on the origin of the normal or wild-type allele. Finally, a significant percentage of patients with PKD and ICCA do not harbor mutations in coding regions of PRRT2.

\section{Additional file}

Additional file 1: Table S1. PRRT2 Sequencing Primers.

\section{Abbreviations}

PKD, Paroxysmal kinesigenic dyskinesia; EKD1, Episodic kinesigenic dyskinesia; PKC, Paroxysmal kinesigenic choreoathetosis; ICCA, Infantile convulsions and choreoathetosis; BFIE, Benign familial infantile epilepsy; PED, Paroxysmal exercise-induced dyskinesia; PNKD, Paroxysmal non-kinesigenic dyskinesia.

\section{Competing interests}

The authors declare that they have no competing interests.

\section{Authors' contributions}

MSL designed the study, examined research subjects, contributed to the initial draft of the manuscript, and analyzed genetic data. PH extracted DNA from blood specimens, examined research subjects and contributed to the initial draft of the manuscript. JX performed Sanger sequencing, analyzed genetic data, and contributed to the initial draft of the manuscript. AP, DM, and SW examined subjects. All authors reviewed and critiqued the manuscript.

\section{Funding agencies}

At the University of Tennessee Health Science Center, this study was supported by the Neuroscience Institute (MSL), Dystonia Medical Research Foundation (MSL), NIH grants R01NS048458 (MSL) and R01NS069936 (MSL), and the NIH Dystonia Coalition Pilot Projects Program (U54NS065701). PH was supported by NIH/NINDS K02NS057666.

\section{Full financial disclosures}

Dr. Hedera serves on the speakers' bureau for Lundbeck. Dr. Xiao has nothing to disclose. Dr. Puschmann receives research support from governmental funding of clinical research within the Swedish National Health Services (ALF-YF), the Swedish Parkinson Foundation (Parkinsonfonden), and The Swedish Parkinson Academy (SPA); received compensation for travel expenses from The Swedish Dystonia Society (Svensk dystoniförening). Dr. Momčilović has nothing to disclose. Dr. Wu receives research support from NIH-NINDS Pediatric Research Loan Repayment Program and the Tourette Syndrome Association. He is also involved in clinical trials conducted by Genzyme Corporation, Otsuka Pharmaceuticals Inc. and Psyadon Pharmaceuticals Inc. Dr. LeDoux serves on the speakers' bureaus for Lundbeck, Merz, and Teva Neuroscience; serves as an advisor for Merz; serves on the Xenazine Advisory Board for Lundbeck, Inc., and the Botulinum Toxin Type A Advisory Board for Allergan; receives research support from the NIH, Dystonia Medical Research Foundation, and Merz; and receives royalty payments for Animal Models of Movement Disorders (Elsevier).

\section{Acknowledgements}

We gratefully acknowledge the assistance of Y. Zhao, S. Vemula, and K. Marshall with sample processing.

\section{Author details}

${ }^{1}$ Department of Neurology, Vanderbilt University, Nashville, TN, USA. 2 Departments of Neurology, and Anatomy and Neurobiology, University of Tennessee Health Science Center, 855 Monroe Avenue, Suite 415 Link Building, Memphis, TN 38163, USA. ${ }^{3}$ Department of Neurology, Skåne University Hospital and Department of Neurology, Lund University, Lund, Sweden. ${ }^{4}$ Clinic for Child Neurology and Psychiatry, Medical Faculty University of Belgrade, Belgrade, Serbia. ${ }^{5}$ Department of Pediatrics, University of Cincinnati, Cincinnati, $\mathrm{OH}$, USA. 
Received: 26 May 2012 Accepted: 16 September 2012

Published: 18 September 2012

\section{References}

1. Bruno MK, Hallett M, Gwinn-Hardy K, Sorensen B, Considine E, Tucker S, Lynch DR, Mathews KD, Swoboda KJ, Harris J, Soong BW, Ashizawa T, Jankovic J, Renner D, Fu YH, Ptacek LJ: Clinical evaluation of idiopathic paroxysmal kinesigenic dyskinesia: new diagnostic criteria. Neurology 2004, 63:2280-2287.

2. Bhatia KP: Paroxysmal dyskinesias. Mov Disord 2011, 26:1157-1165.

3. Chen WJ, Lin Y, Xiong ZQ, Wei W, Ni W, Tan GH, Guo SL, He J, Chen YF, Zhang QJ, Li HF, Lin Y, Murong SX, Xu J, Wang N, Wu ZY: Exome sequencing identifies truncating mutations in PRRT2 that cause paroxysmal kinesigenic dyskinesia. Nature Genet 2011, 43:1252-1255.

4. Wang JL, Cao L, Li XH, Hu ZM, Li JD, Zhang JG, Liang Y, San A, Li N, Chen SQ, Guo JF, Jiang H, Shen L, Zheng L, Mao X, Yan WQ, Zhou Y, Shi YT, Ai SX, Dai MZ, Zhang P, Xia K, Chen SD, Tang BS: Identification of PRRT2 as the causative gene of paroxysmal kinesigenic dyskinesias. Brain 2011, 134:3493-3501.

5. Li J, Zhu X, Wang X, Sun W, Feng B, Du T, Sun B, Niu F, Wei H, Wu X, Dong $L$, Li L, Cai $X$, Wang $Y$, Liu $Y$ : Targeted genomic sequencing identifies PRRT2 mutations as a cause of paroxysmal kinesigenic choreoathetosis. $J$ Med Genet 2012, 49:76-78.

6. Liu Q, Qi Z, Wan XH, Li JY, Shi L, Lu Q, Zhou XQ, Qiao L, Wu LW, Liu XQ Yang W, Liu Y, Cui LY, Zhang X: Mutations in PRRT2 result in paroxysmal dyskinesias with marked variability in clinical expression. J Med Genet 2012, 49:79-82.

7. Heron SE, Grinton BE, Kivity S, Afawi Z, Zuberi SM, Hughes JN, Pridmore C, Hodgson BL, Iona X, Sadleir LG, Pelekanos J, Herlenius E, Goldberg-Stern H, Bassan H, Haan E, Korczyn AD, Gardner AE, Corbett MA, Gécz J, Thomas PQ, Mulley JC, Berkovic SF, Scheffer IE, Dibbens LM: PRRT2 mutations cause benign familial infantile epilepsy and infantile convulsions with choreoathetosis syndrome. Am J Hum Genet 2012, 90:152-160.

8. Cao L, Huang XJ, Zheng L, Xiao Q, Wang XJ, Chen SD: Identification of a novel PRRT2 mutation in patients with paroxysmal kinesigenic dyskinesias and c.649dupC as a mutation hot-spot. Parkinsonism Relat Disord 2012, 18:704-706.

9. Ono S, Yoshiura KI, Kinoshita A, Kikuchi T, Nakane Y, Kato N, Sadamatsu M, Konishi T, Nagamitsu S, Matsuura M, Yasuda A, Komine M, Kanai K, Inoue T, Osamura T, Saito K, Hirose S, Koide H, Tomita H, Ozawa H, Niikawa N, Kurotaki N: Mutations in PRRT2 responsible for paroxysmal kinesigenic dyskinesias also cause benign familial infantile convulsions. J Hum Genet 2012, 57:338-341.

10. Lee HY, Huang Y, Bruneau N, Roll P, Roberson ED, Hermann M, Quinn E, Maas J, Edwards R, Ashizawa T, Baykan B, Bhatia K, Bressman S, Bruno MK, Brunt ER, Caraballo R, Echenne B, Fejerman N, Frucht S, Gurnett CA, Hirsch E, Houlden H, Jankovic J, Lee WL, Lynch DR, Mohamed S, Müller U, Nespeca MP, Renner D, Rochette J, et al: Mutations in the novel protein PRRT2 cause paroxysmal kinesigenic dyskinesia with infantile convulsions. Cell Rep. 2012, 1:2-12.

11. Schubert J, Paravidino R, Becker F, Berger A, Bebek N, Bianchi A, Brockmann K, Capovilla G, Dalla Bernardina B, Fukuyama Y, Hoffmann GF, Jurkat-Rott K, Antonnen AK, Kurlemann G, Lehesjoki AE, Lehmann-Horn F, Mastrangelo M, Mause U, Müller S, Neubauer B, Püst B, Rating D, Robbiano A, Ruf S, Schroeder C, Seidel A, Specchio N, Stephani U, Striano P, Teichler J, et al: PRRT2 mutations are the major cause of benign familial infantile seizures (BFIS). Hum Mutat 2012, 33:1439-1443.

12. Spacey SD, Valente EM, Wali GM, Warner TT, Jarman PR, Schapira AH, Dixon $\mathrm{PH}$, Davis MB, Bhatia KP, Wood NW: Genetic and clinical heterogeneity in paroxysmal kinesigenic dyskinesia: evidence for a third EKD gene. Mov Disord 2002, 17:717-725.

13. Valente EM, Spacey SD, Wali GM, Bhatia KP, Dixon PH, Wood NW, Davis MB: A second paroxysmal kinesigenic choreoathetosis locus (EKD2) mapping on 16q13-q22.1 indicates a family of genes which give rise to paroxysmal disorders on human chromosome 16. Brain 2000, 123:2040-2045.

14. Tomita H, Nagamitsu S, Wakui K, Fukushima Y, Yamada K, Sadamatsu M, Masui A, Konishi T, Matsuishi T, Aihara M, Shimizu K, Hashimoto K, Mineta M, Matsushima M, Tsujita T, Saito M, Tanaka H, Tsuji S, Takagi T, Nakamura Y, Nanko S, Kato N, Nakane Y, Niikawa N: Paroxysmal kinesigenic choreoathetosis locus maps to chromosome 16p11.2-q12.1. Am J Hum Genet 1999, 65:1688-1697.

15. Bennett LB, Roach ES, Bowcock AM: A locus for paroxysmal kinesigenic dyskinesia maps to human chromosome 16 . Neurology 2000, 54:125-130.

16. Szepetowski P, Rochette J, Berquin P, Piussan C, Lathrop GM, Monaco AP: Familial infantile convulsions and paroxysmal choreoathetosis: a new neurological syndrome linked to the pericentromeric region of human chromosome 16. Am J Hum Genet 1997, 61:889-898.

17. Lee WL, Tay A, Ong HT, Goh LM, Monaco AP, Szepetowski P: Association of infantile convulsions with paroxysmal dyskinesias (ICCA syndrome): confirmation of linkage to human chromosome 16p12-q12 in a Chinese family. Hum Genet 1998, 103:608-612.

18. Silva $A L$, Romão $L$ : The mammalian nonsense-mediated mRNA decay pathway: to decay or not to decay! Which players make the decision? FEBS Lett 2009, 583:499-505.

19. Tan EC, Li H: Characterization of frequencies and distribution of single nucleotide insertions/ deletions in the human genome. Gene 2006, 376:268-280.

doi:10.1186/1471-2377-12-93

Cite this article as: Hedera et al:: Novel PRRT2 mutation in an AfricanAmerican family with paroxysmal kinesigenic dyskinesia. BMC Neurology 2012 12:93

\section{Submit your next manuscript to BioMed Central and take full advantage of:}

- Convenient online submission

- Thorough peer review

- No space constraints or color figure charges

- Immediate publication on acceptance

- Inclusion in PubMed, CAS, Scopus and Google Scholar

- Research which is freely available for redistribution 